Original Article

\title{
Biochemical and morphological effects of sodium butyrate on Dictyostelium discoideum development
}

\author{
Luis Boto, Amparo Cano and Angel Pestaña ${ }^{1}$ \\ Instituto de Investigaciones Biomédicas, CSIC. Facultad de Medicina, UAM. Arzobispo Morcillo, 4. \\ 28029 Madrid. Spain (1address for offprints).
}

Received 5 September 1986

Keywords: dictyostelium, butyrate, cAMP metabolism, discoidins, terminal differentiation, histone acetylation

\begin{abstract}
Pretreatment of proliferating $D$. discoideum amoebae with $10 \mathrm{mM}$ butyrate for at least $8 \mathrm{~h}$ (one duplicating time) induced a reversible and dose dependent premature expression of several developmental parameters when the cells were starved in the absence of the fatty acid. The aggregative phase of the morphogenetic cycle was reduced in $2 \mathrm{~h}$ and the appearance of mature fruiting bodies and spores took place $4 \mathrm{~h}$ earlier as a result of butyrate pretreatment. Some developmentally regulated proteins, such as contact-sites A, cell surface lectins and cyclic AMP phosphodiesterase were also expressed $2 \mathrm{~h}$ earlier in butyrate pretreated cells than in controls. The level of extracellular cyclic AMP was reduced in butyrate pretreated cells, while other parameters of cyclic AMP metabolism were not affected. Butyrate also caused a partial inhibition of growth and the hyperacetylation of histone $\mathrm{H} 4$ in growing amoeba. These results suggest that butyrate acts as an inducer of differentiation in $D$. discoideum and can therefore be used as an experimental tool in order to explore regulatory mechanisms operating in slime mold differentiation.
\end{abstract}

Abbreviations: MES-2-N-morpholinoethanesulfonate; EDTA-ethylendiaminotetracetate; TCA-trichloroacetate; DTT-dithiothreitol; SDS-sodium dodecylsulfate

\section{Introduction}

Several reports have shown that $n$-butyrate and other lipophilic compounds can switch the phenotype of embryonic and transformed cells to the phenotype of differentiating cells [1]. Millimolar concentrations of sodium butyrate reversibly induce several morphological and biochemical modifications when present in the cell growth medium for at least one cell cycle. In one of the most outstanding examples of butyrate action, Friend erythroleukemia cells [2] were induced to differentiate to globin producing erythroid cells; an effect which was coordinated with the accumulation of new unique sequences of gene RNA transcripts and the induction of new protein synthesis [3]. Butyrate has also been shown to induce hyperacetylation of histones $[1,4]$ and the synthesis of polypeptide hormones, glycoproteins or enzymes in several cell lines [reviewed in 1].

On the basis of these observations it was hypothesized that butyrate and other inducers of differentiation could be useful for the study of the regulatory mechanisms operating in the develop- 
ment of Dictyostelium discoideum; a lower eukaryote in which cell proliferation and differentiation are dissociated. Upon starvation, the amoebae move towards attracting centers by a well known mechanism of cyclic AMP relay [5] and subsequently they organize into discrete aggregates from which terminal differentiation to sporocarps occurs [6]. In this report we show that the presence of $10 \mathrm{mM}$ sodium butyrate in the vegetative growth phase of Dictyostelium induced a general shortening in the morphogenetic developmental program, when the amoebae were allowed to differentiate in the absence of the fatty acid. These results are discussed in the light of known regulatory mechanisms operating in $D$. discoideum development.

\section{Material and methods}

\section{Growth and developmental conditions}

Dictyostelium discoideum, strain Ax-2, was axenically grown in HL-5 medium as described [7]. When indicated, n-butyrate or other short chain fatty acids were added to the medium at a final concentration of $10 \mathrm{mM}$. Cells were usually grown up to densities of $2-4 \times 10^{6}$ cells $/ \mathrm{ml}$. Starvation was initiated by washing the cells three times in distilled water. For development on solid support, washed cells were resuspended at the indicated densities in MES-PDF buffer containing per liter: $1.5 \mathrm{gr}$ of MES (from Sigma), $1.5 \mathrm{gr} \mathrm{KCl}, 0.6 \mathrm{gr}$ $\mathrm{MgSO}_{4} .6 \mathrm{H}_{2} \mathrm{O}, 0.5 \mathrm{mg}$ Streptomycin, $\mathrm{pH} 6.5$ and plated on Millipore filters (HABPO 4700 or 1300) saturated with MES-PDF buffer and supported on Millipore prefilters AP1004700 wetted in the same buffer. Filters were incubated in a humid chamber at $22{ }^{\circ} \mathrm{C}$. For studies in suspension, cells were resuspended in $17 \mathrm{mM} \mathrm{Na}{ }^{+} / \mathrm{K}^{+}$phosphate buffer $\mathrm{pH} 6.0$ at the indicated densities, and incubated at $22^{\circ} \mathrm{C}$ in a New Brunswick gyratory bath at $140 \mathrm{rpm}$. Microphotographs were taken on Plus X-120 film (Kodak) using a Nikon Stereoscopic microscope SM with a $4 \times$ plain objective and lateral lighting. Cells or spores were counted in a hemocytometer after dissociation in $17 \mathrm{mM}$ $\mathrm{Na}^{+} / \mathrm{K}^{+}$phosphate containing $10 \mathrm{mM}$ EDTA.

\section{EDTA-resistant contacts}

The appearance of contact sites $\mathrm{A}$ was estimated in cells developing on filters as described [8], except that the developmental medium was the MES-PDF buffer described above. At the indicated time points, cells were dissociated from the filters by vortexing and pipeting in test tubes containing $2 \mathrm{ml}$ of MES-PDF, supplemented with $10 \mathrm{mM}$ EDTA. The dissociated cells were allowed to reaggregate in a gyrotary bath for $20 \mathrm{~min}$ at $22^{\circ} \mathrm{C}$. The proportion of cells remaining as single or doublets after this incubation was taken as a measurement of cell adhesion.

\section{Purification and assay of discoidins}

Discoidins were obtained from $1 \times 10^{8}$ cells by sonication in ECT buffer $\left(75 \mathrm{mM} \mathrm{Na}{ }^{+}, 75 \mathrm{mM}\right.$ $\mathrm{K}^{+}, 165 \mathrm{mM} \mathrm{Cl}^{-}, 1 \mathrm{mM}$ EDTA, $15 \mathrm{mM}$ Tris $\mathrm{pH}$ 7.3) followed by centrifugation at $100000 \times \mathrm{g}$ for $60 \mathrm{~min}$. Almost $95 \%$ pure discoidins were obtained by affinity chromatography of these supernatants on Sepharose-4B [9]. The hemagglutination activity of discoidins in crude extracts or purified preparations was measured with formalinized rabbit erythrocytes using a two-fold serial dilutions in microtitter V-plates, as described [10]. A unit of hemagglutination activity is defined as the last dilution at which agglutination is achieved.

\section{Synthesis of discoidins}

Discoidin synthesis was determined by pulse labelling with $\left({ }^{3} \mathrm{H}\right)$ leucine of cells developing in suspension $\left(3-4 \times 10^{7}\right.$ cells $\left./ \mathrm{ml}\right)$. Incubation in the presence of 50 microCi of $\left(\mathrm{H}^{3}\right)$ leucine (153 Ci/mmol from Amersham) per $10^{8}$. cells was at $22^{\circ} \mathrm{C}$ for $2 \mathrm{~h}$ in a gyratory bath $(140 \mathrm{rpm})$. After the labelling period, cells were washed three times in ECT buffer and resuspended at the density of $2 \times 10^{8}$ cells $/ \mathrm{ml}$ in the same buffer. Radioactivity in discoidins was measured after purification as described before and the rate of leucine incorporation in discoidins was corrected for the leucine content of these lectins [9]. 
Measurement of cyclic AMP

Total cyclic AMP was measured in cells developing in moist filters following the procedure described by Brenner [11], except that the filtration step was omitted. Cyclic AMP recovery was $40 \%$ on average as estimated by the addition of a tracer amount of ${ }^{3} \mathrm{H}$ cyclic AMP to the filters before TCA extraction. Cyclic AMP was measured by a binding assay [12], using the kit supplied by Amersham, with a sensitivity of 0.5 pmole.

\section{Cyclic AMP phosphodiesterase activity}

This activity was assayed following the conversion of $\left({ }^{3} \mathrm{H}\right) 3^{\prime}-5^{\prime}$ cyclic AMP to $\left({ }^{3} \mathrm{H}\right) 5^{\prime}$ AMP by homogenates from cells allowed to differentiate on filters. The reaction mixture contained in $0.2 \mathrm{ml}$, 0.5 microCi of $\left({ }^{3} \mathrm{H}\right)$ cyclic AMP $(25 \mathrm{Ci} / \mathrm{mmol}$ from Amersham), 15 nmole of unlabelled cyclic AMP, 1 micromole of $\mathrm{MgCl}_{2}, 8$ micromole Tris$\mathrm{HCl} \mathrm{pH} 8.0$ and 20 microliter of the whole cell lysate. After $15 \mathrm{~min}$ at $22^{\circ} \mathrm{C}$ in a shaker incubator, the reaction was stopped by boiling for $1 \mathrm{~min}$ followed by freezing in ethanol-dry ice. The reaction products were separated by thin layer chromatography [13]. Units of phosphodiesterase activity are given in nmoles of cyclic AMP hydrolyzed under the assay conditions.

\section{Assay of adenylate cyclase activity}

At the indicated time intervals cells developing in solid support were detached from the filters by extensive washing with MES-PDF and were then collected by centrifugation. The cell pellet was resuspended in TAES buffer ( $25 \mathrm{mM}$ Tris-acetate $\mathrm{pH} 7.5,1 \mathrm{mM}$ EDTA, $1 \mathrm{M}$ saccharose) at the final density of $1-2 \times 10^{8}$ cells $/ \mathrm{ml}$ and homogenized with 50 strocks in a $1 \mathrm{ml}$ glass-glass homogenizer. The assay conditions were basically as described [14], using $0.02-0.03 \mathrm{ml}$ of homogenate in $0.1 \mathrm{ml}$ of the assay mixture containing $1 \mathrm{mM}$ ATP and 0.7 microCi of $\left(\alpha^{-32} \mathrm{P}\right)$ ATP. After $10 \mathrm{~min}$ at $25^{\circ}$, the reaction was stopped by the addition of $0.1 \mathrm{ml}$ of a mixture containing $1 \%$ SDS, $1 \mathrm{mM}$ cyclic AMP, $10 \mathrm{mM}$ EDTA, $50 \mathrm{mM}$ Tris-acetate $\mathrm{pH} 7.5$. After the addition of $0.8 \mathrm{ml}$ of distilled water and 0.2 microCi of $\left({ }^{3} \mathrm{H}\right)$ cyclic AMP as a marker for recovery, the reaction mixture was chromatographied as described by Salomon et al. [15] and the ( $\left.{ }^{32} \mathrm{P}\right)$ cyclic AMP measured by the Cherenkov radiation [16]. Units of adenylate cyclase activity are given in picomoles of cyclic AMP formed under the standard assay conditions.

\section{Isolation of histones}

Histones were isolated from nuclear suspensions following the procedure developed by Mende et al. [17] for Physarum policephalum, using 40\% guanidine $\mathrm{HCl}$ for the extraction and ion exchange chromatography in Bio Rex 70 (from Bio Rad). The fraction eluted with $12 \%$ guanidine $\mathrm{HCl}$ was found enriched in the four core histones as ascertained by SDS acrylamide electrophoresis.

\section{Other analytical methods}

Histones were analyzed in polyacrylamide gel slabs using the SDS system described by Laemmli [24] or the urea-acetic acid-Triton from Bonner et al. [25]. The gels were stained with Coomassie blue and dried at $40^{\circ} \mathrm{C}$ between two acetate sheets. The resulting transparencies were scanned with a Quickscan densitometer. Binding of cyclic AMP to whole cells was assayed using procedures described [26]. Protein was measured by the Lowry [27] and Bradford methods [28] using bovine serum albumin as standard.

\section{Results}

Growth of D. discoideum in the presence of $n$ butyrate

Cell proliferation of $D$. discoideum, axenic strain Ax2, was diminished when n-butyrate was present in the medium. Concentrations of the fatty acid be- 
Table 1. Summary effects of short chain fatty acids on D. discoideum growth and development.

\begin{tabular}{|c|c|c|c|c|}
\hline Treatment ${ }^{\mathrm{a}}$ & $\begin{array}{l}\text { Doubling time } \\
\text { (hours) }\end{array}$ & $\begin{array}{l}\text { Streaming } \\
\text { (hours) }\end{array}$ & $\begin{array}{l}\text { Contact sites } \\
(0 \%)\end{array}$ & $\begin{array}{l}\text { Spore yielde } \\
(\%)\end{array}$ \\
\hline \multicolumn{5}{|l|}{ Experiment I } \\
\hline Control & 8 & 9.5 & n.d. & 0.5 \\
\hline Butyrate $1 \mathrm{mM}$ & 8.7 & 9 & n.d. & 0.6 \\
\hline Butyrate $2.5 \mathrm{mM}$ & 9.1 & 9 & n.d. & 0.7 \\
\hline Butyrate $5 \mathrm{mM}$ & 9.4 & 8 & n.d. & 4 \\
\hline Butyrate $10 \mathrm{mM}$ & 13.5 & 7 & n.d. & 51.6 \\
\hline \multicolumn{5}{|l|}{ Experiment II } \\
\hline Control & 8.7 & $9-10$ & 22 & 2 \\
\hline Butyrate $\quad 10 \mathrm{mM}$ & 13.7 & 7 & 72 & 61 \\
\hline Propionate $10 \mathrm{mM}$ & 10 & $9-10$ & 14 & 30 \\
\hline Isobutyrate $10 \mathrm{mM}$ & 10.5 & $8-9$ & 24 & 86 \\
\hline
\end{tabular}

aAmoebae were grown for three days in the presence of fatty acids as indicated. Cells were harvested at densities of $2-4 \times 10^{6} / \mathrm{ml}$, washed and allowed to develop on Millipore filters as indicated in Material and methods; b Average of three observations; ${ }^{\mathrm{c}} \mathrm{Hours}$ after the onset of starvation in which dendritic aggregation streams are seen (two experimental observations); ${ }^{\mathrm{d}}$ EDTA-resistant cell aggregates as a percent of the total cell in suspension (cells were detached from the filters after $7 \mathrm{~h}$ of starvation). Values from one representative experiment; eSpores counted after $17 \mathrm{~h}$ of starvation as percent of the cells initially plated (triplicate counts from one experiment).

tween 5 and $10 \mathrm{mM}$ increased the doubling time in a $60 \%$ on average, from $8-9$ hours in control to 13-14 hours in treated cells (Table 1). Lower doses of n-butyrate were without effect; other fatty acid analogues such as propionate and isobutyrate were less effective in retarding growth (Table 1).

The inhibition of growth was manifest without any delay after the addition of n-butyrate (Fig. 1A) and was fully reversed two hours after the transfer of the treated amoeba to a fresh medium lacking the agent (Fig. 1B). A similar two hours lag in the recovery of treated cells was observed (Fig. 1C) during the limited growth period which takes place after starvation on solid support of exponentially growing amoeba [23]. In this case, an appreciable

Fig. I. Reversible effects of butyrate on D. discoideum growth. A) Growth retardation of amoeba grown in the presence of $10 \mathrm{mM}$ sodium butyrate. B) Recovery of amoeba growth after butyrate removal. C) Cell number increase after starvation on solid support of control and butyrate pretreated cells. Average of two representative experiments with triplicate cell counts for each time point. Symbols stand for control $(\bullet)$ and butyrate treated cells $(\boldsymbol{A})$.

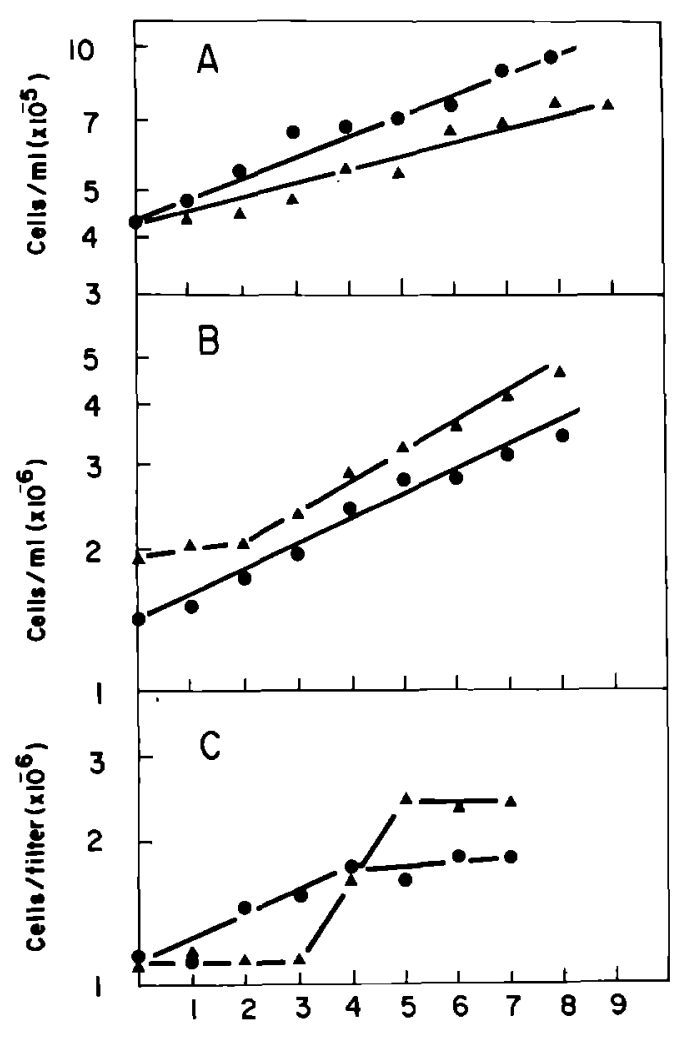

TIME AFTER CHANGE ( $h$ ) 
degree of synchrony was observed, suggesting that butyrate might be retarding some specific step along the cell cycle.

\section{Effect of $n$-butyrate pretreatment on $\mathrm{D}$. discoideum development}

One of the most outstanding effects of butyrate and other inducers is their ability to commit inmature or transformed cells to terminal differentiation in the absence of the agent and after a period of exposure to it [24]. In order to explore the presumptive effects of n-butyrate on the terminal differentiation of $D$. discoideum, amoeba grown in the presence of the fatty acid were washed free of nutrients and allowed to differentiate on solid support in the absence of butyrate. Under these conditions it was observed a general shortening of the morphogenetic pathway as compared to controls (Fig. 2). Dendritic cell streaming, the first morphological appearance of the chemotactic and aggregative phenomena in $D$. discoideum differentiation, was consistently observed after seven hours of development of butyrate pretreated cells, two hours earlier than in controls (Fig. 2D and A).

After 17 hours of development most of the aggregates from butyrate pretreated amoeba were close to the final morphogenetic stage of mature sporocarps (Fig. 2F), while the controls were still near the 'mexican hat' stage of development (Fig. 2E). Confirming this speed up of the morphogenetic processes, the spore yield after $17 \mathrm{~h}$ of development was very high in pretreated cells as compared to controls (Table 1). No differences were observed in the number or size of the fruiting bodies produced by treated cells as compared to controls and the final spore yield was the same in both cases. These observations would indicate that $n$ butyrate pretreatment induces a shortening of the normal expression of the morphogenetic program in $D$. discoideum, without affecting the final result of the process. A whole picture of the morphogenetic effects of n-butyrate pretreatment is shown in the scheme at the bottom of Fig. 2 .

\section{Requirements for optimal $n$-butyrate effects}

The dose-dependence study of butyrate pretreatment on developmental processes showed (Table 1, Fig. 2A to D) an optimum at the concentration of 5-10 mM. Higher concentrations in the growth medium were deleterious for the cell viability and the presence of the fatty acid during starvation resulted in a considerable retardation of developmental processes (not shown). Other fatty acid analogues such as propionic and isobutyric acid were less effective or had distinct effects on $D$. discoideum growth and development (Table 1).

The developmental effects of butyrate were only observed when the pretreated amoeba were collected in exponential growth (data not shown), suggesting the involvement of cell cycle associated phenomena. Besides this requirement for active growth, the effects of butyrate pretreatment were shown to be dependent on the length of the exposure to the agent, with an optimum of $8-10 \mathrm{~h}$, as ascertained by the criteria of spore production after $18 \mathrm{~h}$ of fasting (Fig. 3A) and the reduction of the preaggregative interphase (data not shown).

The reversibility of the morphogenetic effects of butyrate pretreatment also showed a requirement for active growth in the absence of the fatty acid for at least $10 \mathrm{~h}$ (Fig. 3B). Interestingly, this study also showed that a maximal effect of butyrate pretreatment on terminal differentiation occurred after 4-6 h of growth in the absence of the drug.

\section{Acquisition of aggregation competence}

In order to explore the mechanisms underlying the more rapid expression of aggregation competence in butyrate pretreated cells, the appearance of contact sites A was studied. As shown in Fig. 4A, EDTA resistant cell aggregation was fully developed in butyrate pretreated cells after $7 \mathrm{~h}$ of fasting on solid support, $2 \mathrm{hr}$ earlier than in the controls.

Besides contact sites $\mathrm{A}$, which have been identified with membrane glycoproteins [25], two carbohydrate binding proteins - discoidin I and II are developmentally regulated during the aggregative phase [26] and seem to be implicated in the 


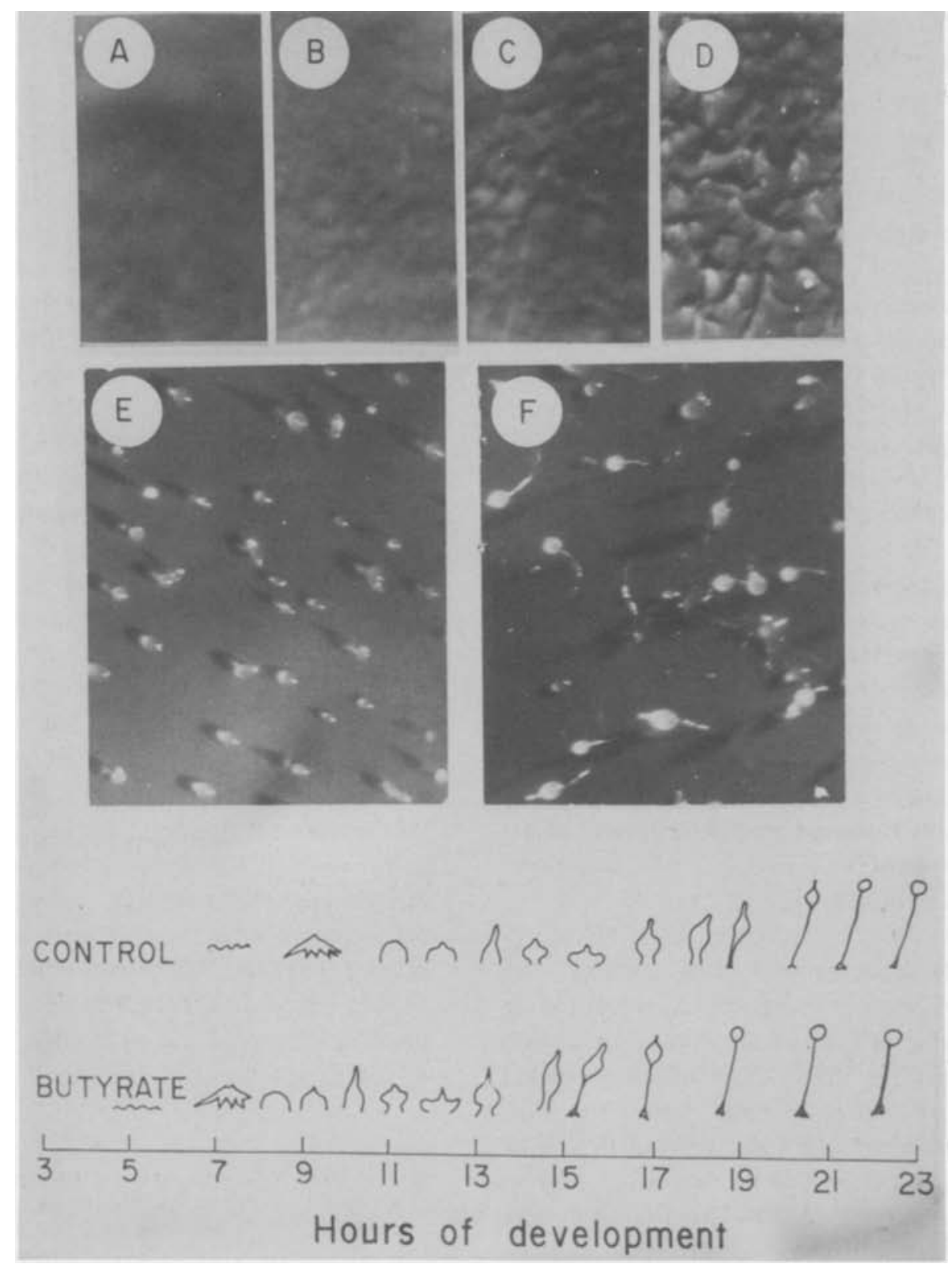

Fig. 2. Morphogenetic effects of n-butyrate on Dictyostelium discoideum. Amoebae were grown in the absence (A, E) or in the presence of n-butyrate at the concentrations of $1 \mathrm{mM}(\mathrm{B}), 5 \mathrm{mM}(\mathrm{C})$ and $10 \mathrm{mM}(\mathrm{D}, \mathrm{F})$. After three days, cells were washed and allowed to develop on filters as indicated in Material and Methods. Photographs were taken $7 \mathrm{~h}(\mathrm{~A}, \mathrm{~B}, \mathrm{C}, \mathrm{D})$ and $17 \mathrm{~h}(\mathrm{E}, \mathrm{F})$ after the onset of starvation. The scheme at the bottom of the figure represents the integrated picture of several observations after 10 mM butyrate pretreatment.

cell-adhesion processes in $D$. discoideum [27]. As shown in Fig. 4B, the maximum rate of discoidin synthesis in butyrate pretreated cells was attained after $6 \mathrm{~h}$ of development, representing a $7.5 \%$ of the total protein synthesized at that time. In con- trols, the maximum rate of discoidin synthesis took place two hours later and represented a $6.5 \%$ of the total protein synthesized in that period. This timing is in good agreement with previous reports showing a maximum label of discoidins between $7-9 \mathrm{~h}$ af- 


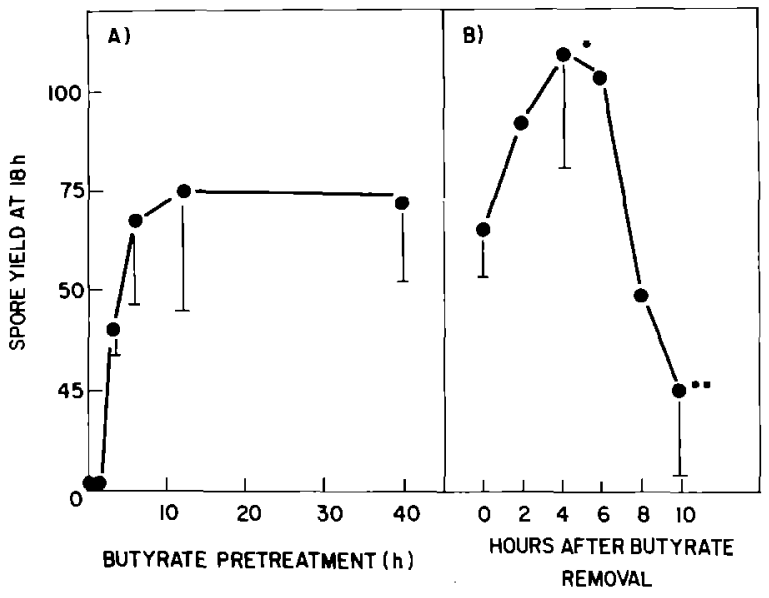

Fig. 3. Minimal time required for n-butyrate action and reversion on terminal differentiation. A) Amoeba were grown in the presence of $10 \mathrm{mM}$ butyrate for the indicated time periods. The washed cells were then allowed to differentiate on solid support. B) Amoeba grown in the presence of $10 \mathrm{mM}$ butyrate for $36 \mathrm{~h}$ were washed and resuspended in growing medium lacking the fatty acid. At the indicated time periods, cells were collected, washed and allowed to differentiate in solid support. Spore yield after $18 \mathrm{~h}$ of development was recalculated as percent of the number of cells initially plated. Average of at least 5 experimental points \pm standard deviation. ${ }^{*} \mathrm{p} \leq 0.05,{ }^{* *} \mathrm{p} \leq 0.005$ vs time 0 (after $36 \mathrm{~h}$ of continuous growth in the presence of $10 \mathrm{~mm}$ butyrate).

ter the onset of development of $\mathrm{NC}-4$ cells, amounting to near $6 \%$ of the newly synthesized protein in this period [26].

Fig. $4 \mathrm{c}$ shows the time course of development of lectin activity as ascertained by hemagglutination assays performed with whole cell homogenates. Those from amoeba pretreated with $10 \mathrm{mM}$ butyrate had a peak of hemagglutination $8 \mathrm{~h}$ after the onset of development, two hours earlier than in controls. Similar results were obtained in unpublished experiments in which the temporal expression of discoidin I in cells differentiating on solid support was studied by immunoblotting techniques [27].

\section{Cyclic AMP metabolism in butyrate pretreated cells}

The central role of cAMP in $D$. discoideum

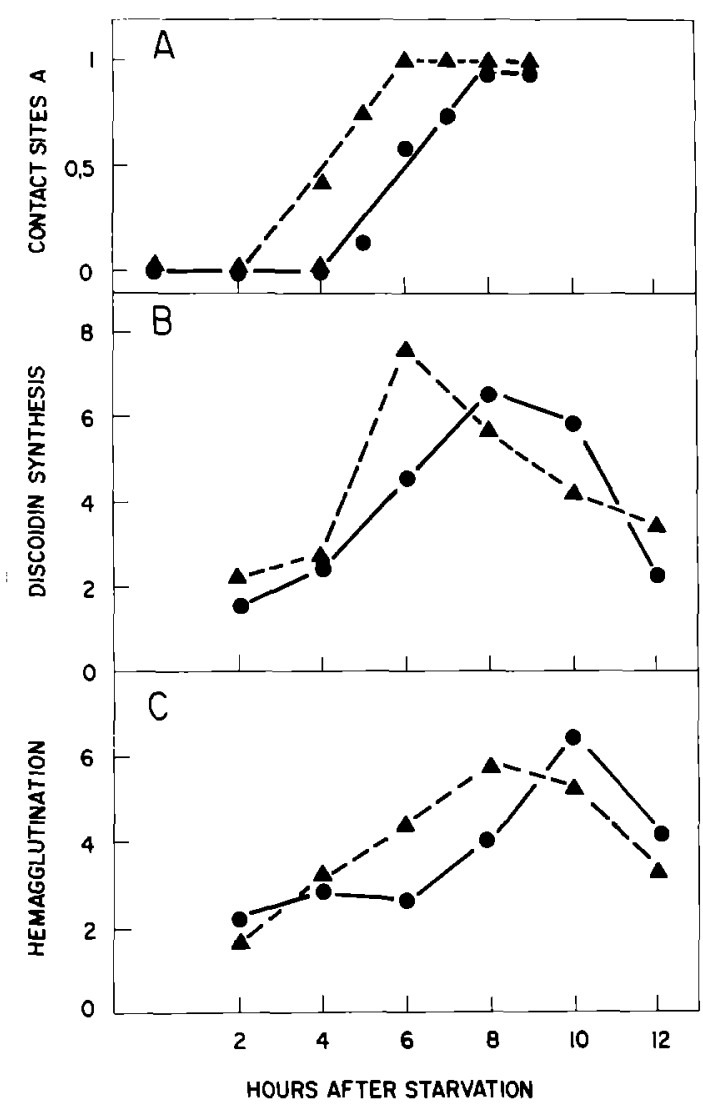

Fig. 4. Influence of butyrate pretreatment on the development of the aggregative competence. A) EDTA-resistant aggregation was measured as described in Material and Methods in cells allowed to develop on filters. The results are expressed as the reciprocal of the fraction of cells remaining as single or double after EDTA treatment ( 0 correspond to the basal value of $0.15-0.20$ and 1 correspond to the maximal aggregation of $0.80-0.90)$. B) Synthesis of discoidins and C) hemagglutination activity in cells developing in suspension after butyrate pretreatment. Beginning at time 0 , aliquots were pulse labelled with ${ }^{3} \mathrm{H}$ leucine at 2 hour intervals. Discoidins were purified and assayed for leucine incorporation as described in Material and Methods. Hemagglutination activity was assayed in crude extracts as described in methods. Symbols stand for cells grown in the absence $(\bullet$ ) or in the presence $(4)$ of $10 \mathrm{mM}$ butyrate for 3 days. In $A$ it is shown the result of one typical experiment out of the six carried out. In $B$ and $C$ it is shown the result of two experiments.

chemotaxis led to a study of cyclic nucleotide levels and related enzyme activities in cells allowed to differenciate on solid support. As shown in Fig. 5A, total cyclic AMP (cellular and extracellular) accumulation in butyrate pretreated cells was 


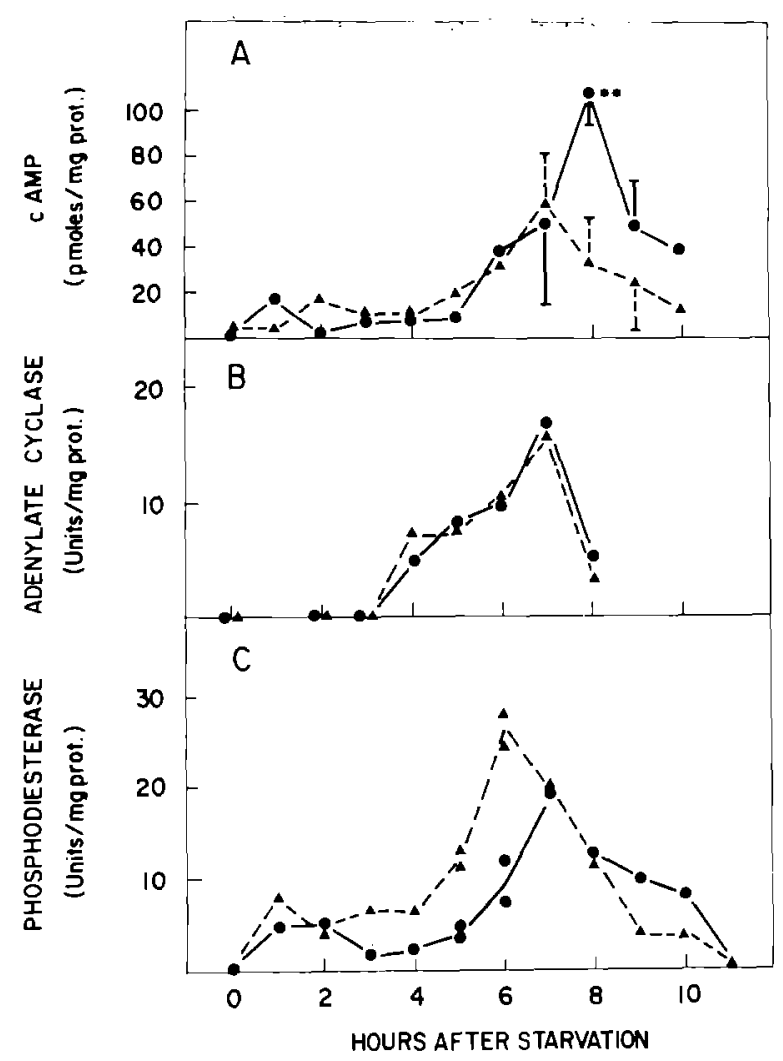

Fig. 5. Cyclic AMP metabolism during differentiation on solid

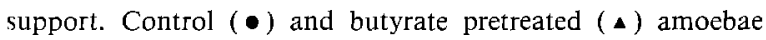
were allowed to develop on filters. Total cyclic AMP (A), adenylate cyclase (B), and cell bound cyclic AMP phosphodiesterase (C) were assayed at the indicated time intervals, as described in Material and Methods. Results in A are average of five independent experiments \pm standard deviation; ${ }^{* *} \mathrm{p} \leq 0.005$ vs butyrate pretreated after 7 and $8 \mathrm{~h}$ of fasting. In $B$ it is shown the average of three experiments. In $\mathrm{C}$ it is shown the results of two experiments.

lower and peaked earlier than in controls. Butyrate pretreatment also resulted in a precocious accumulation of cell-bound phosphodiesterase but was without effect on the developmental pattern of adenylate cyclase (Fig. 5B and C). Similar results were obtained in unpublished studies carried out with cells allowed to differentiate in suspension. These studies also showed that the developmental pattern of extracellular phosphodiesterase and cyclic AMP binding were unaffected by n-butyrate pretreatment (data not shown).

\section{Histone acetylation in butyrate treated amoeba}

Histone acetylation through inhibition of acetyl group turnover is one of the best known effects of butyrate on eukaryotic cells [1]. In order to study this potential mechanism of butyrate action, a preliminary experiment was designed to ascertain the occurrence of histone acetylation in $D$. discoideum. Isolated nuclei were incubated in the presence of ${ }^{3} \mathrm{H}$ acetate, and the histones were extracted, analyzed in SDS polyacrylamide electrophoresis. The autoradiographic analysis of the dried gel (data not shown) revealed the presence of acetyl groups in a protein band with a mobility close to the marker $\mathrm{H} 4$ histone from calf thymus.

Hyperacetylation of histones in response to butyrate treatment was demonstrated through the electrophoretic analysis of histone subfractions in polyacrylamide slab gels containing urea-acetic acid-Triton [19]. As shown in Fig. 6 the microheterogeneity of histone $\mathrm{H} 4$ subfractions was shifted from the high mobility (low acetylation) forms in controls to the slower mobility (high acetylation) forms in butyrate and isobutyrate treated cells. No differences in the degree of acetylation were observed between control cells whether stationary or exponentially growing.

\section{Discussion}

The presence of n-butyrate during the vegetative phase of $D$. discoideum has been shown to cause a dose dependent and reversible inhibition of the growth of the amoeba as well as a premature expression of several developmentally regulated parameters upon starvation in a medium lacking the fatty acid. The developmental effects could not be attributed to the persistence of butyrate traces during differentiation since the presence of $n$ butyrate during development, at concentrations as low as $0.5-1 \mathrm{mM}$, resulted in a marked inhibition of aggregation and morphogenesis (unpublished). The growth and developmental effects of butyrate in $D$. discoideum are qualitatively similar to those described for $\mathrm{HeLa}$ and Friend erythroleukemic 


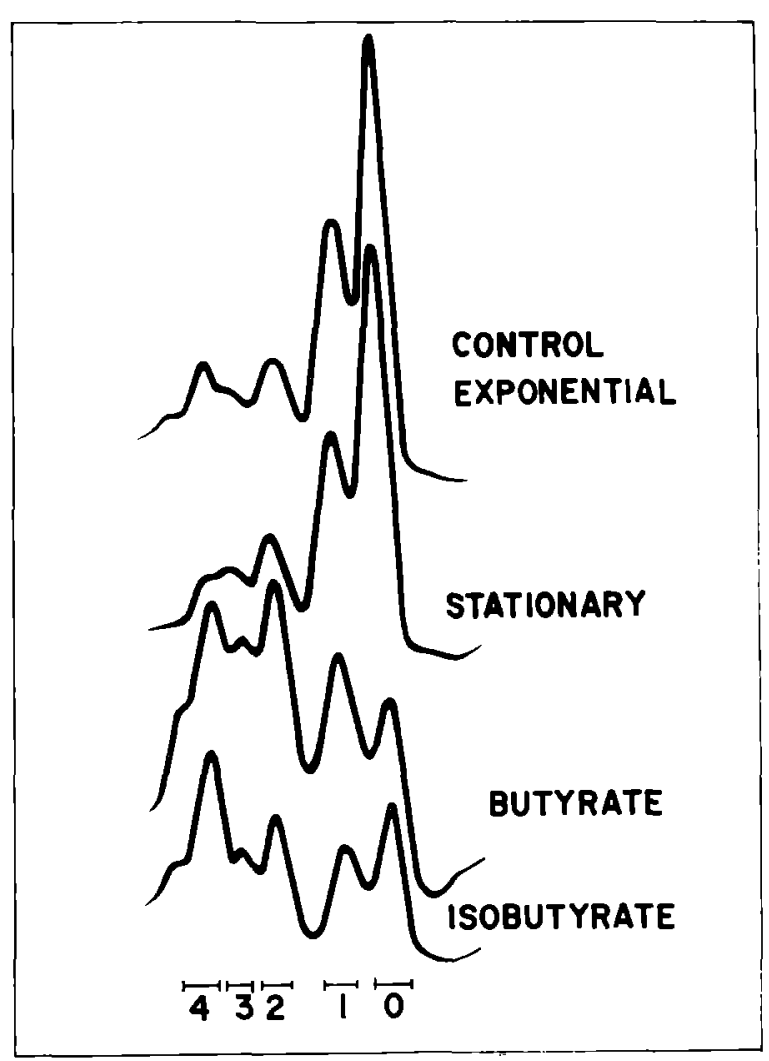

Fig. 6. Sodium butyrate induced microheterogeneity of $\mathrm{H} 4 \mathrm{hi}-$ stones in Dictyostelium discoideum. Histone were isolated from D. Discoideum amoeba grown under the indicated conditions and electrophoresed in the presence of urea-acetic acid-Triton as indicated in Material and Methods. The figure shows a scan of stained gels with indication of the presumptive degree of acetylation from 0 to 4 residues.

cells $[28,2]$. To our knowledge, this is the first report in which n-butyrate was shown to act as an 'inducer of differentiation' in non-mammallian cells.

The precocious expression of EDTA-resistant contact sites in butyrate pretreated cells is in good temporal correlation with the effect of the drug on cell streaming. The synthesis and accumulation of discoidins was also shown to correlate with the morphological developmental effects of butyrate and therefore reinforce the involvement of these lectins in the aggregative phase of $D$. discoideum development. Since discoidin I synthesis is mainly regulated by the accumulation of newly synthesized mRNA transcripts [29], it is not unreasonable to postulate an effect of butyrate at transcriptional level in D. discoideum. This may also account for the premature accumulation of other developmentally regulated proteins such as the cell-bound phosphodiesterase or the glycoproteins involved in the functional expression of contact sites A. In othег cell systems, butyrate has been suggested to modulate specific mRNA synthesis by mechanisms involving the transient hyperacetylation of a histone $\mathrm{H} 4$ subset [30]. The possible involvement of histone acetylation in the effects of butyrate on $D$. discoideum development awaits further investigation.

The study of cyclic AMP metabolism has shown a marked reduction in cyclic nucleotide accumulation during differentiation, as a result of n-butyrate pretreatment. This finding is rather paradoxical in view of the crucial role of cyclic AMP in cell aggregation and differentiation [8, 31], but can be explained within the current conceptual framework of $D$. discoideum development. In fact, as clearly shown by Wier [32] and Nanjundiah and Malchow [33], the time elapsed between starvation and aggregation is significantly shortened by experimental treatments which lowers the cyclic AMP levels surrounding the amoeba or increase the cellbound phosphodiesterase activity. Any of these circumstances or the synergistic effect of both - such as in n-butyrate pretreated cells - would prevent the saturation of the cyclic AMP receptors and therefore increase the efficiency of the chemotactic response.

The mechanism underlying the cytostatic effects of sodium butyrate are unknown. In unpublished observations we have found a partial inhibition of amino acids uptake and protein synthesis in growing amoeba by sodium butyrate which could be explained by direct interference of the fatty acid with cell membrane fluidity. It is also possible that butyrate might be directly acting through a reduction in intracellular $\mathrm{pH}$ [34], although the differential effects of short chain fatty acids on amoeba proliferation (Table 1) argues against a mechanism of action exclusively based on cytoplasmic acidification.

In contrast to the almost instantaneous effects on cell growth (Fig. 1A, B), the developmental effects of butyrate pretreatment required a time inter- 
val of $8-12 \mathrm{~h}$ for optimal action and full reversion (Fig. 3A, B). These intervals, which are within the range of the amoeba doubling time (Table 1), suggest the involvement of cell cycle related phenomena in butyrate action. In other cell systems sodium butyrate was shown to inhibit the transition from early $G_{1}$ to the subsequent phases in the cell cycle [35]. $G_{1}$ cells probably correspond to the light amoeba isolated in isopycnic gradients, which were shown to be more sensitive to cyclic AMP and to form aggregates more rapidly than the heavy cells [36], probably $\mathrm{G}_{2}$ cells. The importance of cell cycle phase on cell fate during development in $D$. discoideum has been recently emphasized $[37,38]$. In view of these observations the putative relationships between cell cycle and developmental effects of sodium butyrate deserve further study.

\section{Acknowledgements}

We are indebted to Prof. Alberto Sols for critical reading and suggestions in the preparation of this manuscript. The skilful technical assistance of Amalia Montes is also acknowledged. This work has been partially supported by the Comisión Asesora de Investigación Científica y Técnica and the Fondo de Investigaciones Sanitarias.

\section{References}

1. Kruh J: Effects of sodium butyrate, a new pharmacological agent, on cells in culture. Mol Cell Biochem 42:65-82, 1982.

2. Leder A, Orkin S, Leder P: Differentiation of erythroleukemic cells in the presence of inhibitors of DNA synthesis. Science 190:893-894, 1975.

3. Reeves R, Cserjesi P: Sodium butyrate induces new gene expression in Friend erythroleukemic cells. J Biol Chem 254:4283-4289, 1979.

4. Doeneck D, Gallwith D: Acetylation of histones in nucleosomes. Mol Cell Biochem 44:113-128, 1982.

5. Mato JM, Konijn TM: Chemosensory transduction in Dictyostelium discoideum, in Biochemistry and Physiology of Protozoa, Academic Press, NY, 1979, Vol 2, pp 181-219.

6. Gerish G, Malchow D: Cyclic AMP receptors and the control of cell aggregation in Dictyostelium discoideum. Adv Cyclic Nucleotide Res 7:49-68, 1976.

7. Watts DJ, Ashworth JM: Growth of mixamoeba of the cel- lular slime mold Dictyostelium discoideum in axenic culture. Biochem J 116:161-170, 1970.

8. Marin FT: Regulation of development in Dictyostelium discoideum. II Regulation of early cell differentiation by amino acid starvation and cellular interactions. Develop Biol 60:389-395, 1977.

9. Frazier W, Rosen S, Reitherman S, Barondes SH: Purification and comparison of two developmentally regulated lectins from Dictyostelium discoideum: discoidin I and II. J Biol Chem 250:7714-7721, 1975.

10. Rosen S, Kafka J, Simpson D, Barondes S: Developmentally regulated carbohydrate-binding proteins in Dict ostelium discoideum. Proc Natl Acad Sci USA 70:2554-2557, 1973.

11. Brenner M: Cyclic AMP levels and turnover during development of the cellular slime mold Dictyostelium discoideum. Develop Biol 64:210-223, 1978.

12. Brown BL, Albano JDM, Ekins RF, Sgherzi AM, Tampion W: A simple and sensitive saturation assay method for the measurement of adenosin $3^{\prime}-5^{\prime}$ cyclic monophosphate. Biochem J 121:561-562, 1971.

13. Rossomando EF, Sussman M: Adenyl cyclase in Dictyostelium discoideum. A possible control element of the chemotactic system. Biochem Biophys Res Comm 47:604-610, 1972.

14. Gunzburg J, Veron M, Brachet P: Non-Michaelis kinetics of adenylate cyclase in Dictyostelium discoideum. Cell Biology Int Report 4:530-540, 1980.

15. Salomon Y, Londos C, Rodbell: A highly sensitive adenylate cyclase assay. Analyt Biochem 58:541-548, 1974.

16. Renart MF, Sebastian J, Mato JM: Adenylate cyclase activity in permeabilized cells from Dictyostelium discoideum. Cell Biol Inter Report 5:1045-1054, 1982.

17. Mende LM, Waterborg JH, Mueller RD, Mathews HR: Isolation, identification and characterization of histones from plasmodia of the true slime mold Physarum polycephalum using extraction with guanidine hydrochloride. Biochemistry $22: 38-51,1983$.

18. Laemmli VK: Cleavage of structural protein during the assembly of the head of bacteriophage T4. Nature 227:680-685, 1970.

19. Bonner WM, West MP, Stedman JD: Two dimensional gel analysis of histones in acid extracts of nuclei and histones. Eur J Biochem 109:17-23, 1980.

20. Klein C, Juliani MH: Cyclic AMP induced changes in cyclic AMP binding sites on Dictyostelium discoideum amocbac. Cell 10:329-335, 1977.

21. Lowry OH, Rosebrough NJ, Farr AL, Randall RJ: Protein measurement with the folin phenol reagent. J Biol Chem 193:265-275, 1951.

22. Bradford MM: A rapid and sensitive method for the quantitation of microgram quantities of protein utilizing the principle of protein-dye binding. Anal Biochem 72:248-255, 1976.

23. Zada Hames I, Asworth JM: The cell cycle and its relationships to development in Dictyostelium discoideum. Dev Biol 63:307-320, 1978. 
24. Marks PM, Rifkind RA, Gambari R, Epner E, Chen Z, Banks J: Commitment to terminal differentiation and the cell cycle, in Currents Topics in Cellular Regulation, Academic Press, 1982 , Vol 21, pp 189-203.

25. Muller R, Gerish G: A specific glycoprotein as the target site of adhesion blocking Fab in aggregating Dictyostelium discoideum. Nature 274:445-449, 1978.

26. Ma G, Firtel R: Regulation of the synthesis of two carbohydrate binding proteins in Dictyostelium. J Biol Chem 253:3924-3932, 1978.

27. Cano A, Pestaña A: The role of membrane lectins in Dictyostelium discoideum aggregation as ascertained by specific univalent antibodies against Discoidin I. J Cell Biochem 25:31-43, 1984 .

28. Hagopian HK, Riggs MG, Swarth, Ingram V: Effect of nbutyrate on DNA synthesis in chick fibroblast and HeLa cells. Cell 12:855-860, 1977.

29. Rowekamp W, Firtel RA: Isolation of developmentally regulated genes from Dictyostelium discoideum. Dev Biol 79:409-418, 1980.

30. Covault J, Perry M, Chalkey R: Effect of histone hyperacetylation and hypoacetylation on RNA synthesis in HTC cells. J Biol Chem 257:13433-13440, 1982.

31. Sampson T, Town C, Gross J: Cyclic AMP and the control of aggregative phase gene expression in Dictyostelium discoideum. Develop Biol 67:54-64, 1978.

32. Wier PW: Cyclic AMP, cyclic AMP phosphodiesterase and the duration of the interphase in Dictyostelium discoideum. Differentiation 9:183-191, 1977.

33. Nanjundiah V, Malchow D: A theoretical study of the effects of cyclic AMP phosphodiesterases during aggregation in Dictyostelium. J Cell Sci 22:49-58, 1976.

34. Aerts R, Durston AJ, Moolenar WH: Cytoplasmic pH and the regulation of the Dictyostelium cell cycle. Cell 43:653-657, 1985.

35. Xue S, Rao P: Sodium butyrate blocks HeLa cells preferentially in early $G_{1}$ phase of the cell cycle. $J$ Cell Sci $52: 163-171,1981$

36. Maeda Y, Maeda M: Heterogeneity of the cell population of the cellular slime mold Dictyostelium discoideum before aggregation, and its relation to the subsequent locations of the cells. Exp Cell Res 84:88-94, 1974.

37. Weijer CJ, Duschl G, David CN: Dependence of cell type proportioning and sorting on cell cycle phase in Dictyostelium discoideum. J Cell Sci 70:133-145, 1984.

38. Sharpe PT, Watts DJ: The role of the cell cycle in differentiation of the cellular slime mould Dictyostelium discoideum. Mol Cell Biochem 67:3-9, 1985. 